\title{
Шляхи підвищення енергоефективності багатозональних VRF систем кондиціювання повітря
}

\section{Н. В. Жихарєва}

Одеська національна академія харчових технологій, вул. Канатна, 112, Одеса, 65039, Україна

\begin{abstract}
Розглянуто шляхи підвищення енергоефективності багатозональних систем кондиціювання повітря, деякі технології і елементи, вдосконалення яких безпосередньо підвищує енергоефективність і знижує споживання електроенергї̈ в річному ичиклі використання систем кондиціювання на основі енергетичних балансів теплофізичних процесів в VRF. За допомогою методів математичного моделювання схемно-технічних рімень $і$ режимів роботи обладнання систем забезпечення мікроклімату в громадських об'єктах при використанні сучасних багатозональних систем кондиціювання розроблена модель підбору багатозональної системи кондиціювання повітря, яка враховує чинники (мінлива температура холодоагенту, інверторний привід, рекуперачія) та обладнання (компресор, вентилятор, теплообмінники, фільтри.) Показані результати розрахунків за розробленою експрес-методикою, яка враховує нестаціонарні тепловологісні зовнішні та внутрішні навантаження $і$ вплив чинників з підбором сучасного обладнання. Можливості енергозбереження проведені при розрахунку універсальної цільової функиії і програм математичного моделювання щчодо визначення термінів окупності та величин цільової функиії для порівнюваних варіантів. Проведений порівняльний аналіз на базі розробленої математичної моделі Daikin, Mitsubishi Electric, Fujitsu, Mitsubishi Неаvу для об'єктів, які працюють протягом добового циклу в екстремально-нестаціонарному режимі.
\end{abstract}

Ключові слова: Оптимізація; Енергозбереження; Кондиціювання повітря; Моделювання;, Нестаціонарне навантаження; Інверторний привід; Компресор; Вентилятор

This is an open access article under the Creative Commons Attribution 4.0 International License (CC BY) http://creativecommons.org/licenses/by/4.0/

(c) The Author(s) 2017.

\section{1. Вступ}

В умовах прискорення науково-технічного прогресу завдання підвищення енергоефективності систем кондиціювання має важливе народногосподарське значення, оскільки іiі рішення, крім підвищення ефективності капітальних вкладень, забезпечує іiї енергозбереження, економію матеріалів, а також поліпшення умов праці людей і навколишнього середовища

Однією $з$ основних завдань цієї комплексної проблеми $є$ енергозбереження. Ми вирішуємо триєдину проблему - оптимізацію (мінімізацію) енергоспоживання при жорсткому дотриманні нормативних вимог до комфортного середовища проживання в житлових, громадських і промислових об'єктах, неухильне дотримання технологічних вимог у виробничих процесах i мінімізацію шкідливого впливу на екологію навколишнього середовища.

Нами розглянуті шляхи підвищення енергоефективності багатозональних систем кондиціювання повітря, деякі технології і елементи, вдосконалення яких безпосередньо підвищує енергоефективність і знижує споживання електроенергії в річному циклі використання систем кондиціювання на основі енергетичних балансів теплофізичних процесів в VRF.
2. Шляхи підвищення енергоефективності багатозональних VRF систем кондиціювання повітря

3 урахуванням підходу до енергоефективних систем $[1,2]$ ми розглядаємо шляхи підвищення ефективності багатозональних систем кондиціювання.

В роботі [3] показано парадокси традиційної методики розрахунку VRF систем кондиціювання повітря.

Основними цільовими напрямами вдосконалення багатозональних систем кондиціювання останнім часом $\epsilon$ такі:

- підвищення комфорту мікроклімату об'єкта, точність і надійність його забезпечення при цілорічної експлуатації;

- підвищення енергоефективності багатозональних систем за рахунок збільшення коефіцієнтів трансформації тепла;

- підвищення показників енергозбереження за рахунок рекуперації та акумуляції теплової енергії і постійного автоматичного оптимального управління режимами роботи, в залежності від сезонних параметрів зовнішнього повітря, сонячної радіації і геотермальних джерел тепла, а також внутрішніх нестаціонарних джерел тепло припливів / тепловтрат і джерела зміни вологості внутрішнього повітря; 
• зниження шкідливого впливу на екологію навколишнього середовища;

- вдосконалення основних агрегатів багатозональної системи кондиціювання повітря: компресора, вентилятора, рекуператора, теплообмінника,

- акумулятор теплоти з використанням тепла фазового переходу, системи управління;

- інтеграція багатозональних систем з сонячними колекторами, системою припливно-витяжної вентиляціï;

- легкість інтеграції з системою "розумного будинку" (BMS з протоколами BACnet або LONwork, порти SC-LGW або SC-BGW);

- перевірочні розрахунки з розробкою монтажної схеми і повної специфікації;

- розробка віддаленого управління і комп'ютерної системи централізованого управління, узгодженого в необхідних випадках 3 пріоритетом індивідуального управління.

\section{1 Підвищення енергоефективності та комфо- рту за рахунок змінної температури холодоаге- нту, інверторного приводу і рекуперації тепла}

Розглянемо аспекти підвищення енергоефективності та комфорту за рахунок змінної температури холодоагенту, інверторного приводу і рекуперації тепла [2].

Мінлива температура холодоагенту, постійно регульована автоматично за величиною поточної сезонної i добової температур зовнішнього середовища і внутрішньої температури, що залежить так само від теплового навантаження внутрішніх джерел/ стоків тепла і зміни вологості повітря та дозволяє отримати високі величини EER, COP і особливо високі сезонні величини ESEER, SCOP.

Технологія використання змінної температури холодоагенту, наприклад в серії VRV IV [2], забезпечує максимальне значення сезонної ефективності ESEER = 8. Ця технологія заснована на інтелектуальній системі управління 3 повним інверторним приводом і системою датчиків, які досліджують температуру і вологість в приміщенні і зовнішнього середовища, наявність людей в приміщенні і концентрацію $\mathrm{CO}_{2}$. Вбудований мікропроцесор розрахує поточне теплове навантаження і вибирає оптимальну температуру і витрату хладагента, що забезпечує оптимальну сезонну ефективність, а по концентрації $\mathrm{CO}_{2}$ - витрату свіжого повітря в припливно-витяжній вентиляції, інтегрованої в систему багатозональних систем.

Інверторний привід, що забезпечує зміну частоти обертання безколекторного синхронного електродвигуна на внутрішніх неодимових магнітах, дозволяє при змінному тепловому навантаженні працювати компресору з високим ККД в практично оптимальному режимi.

Для одночасної роботи частини внутрішніх блоків на охолодження, а інших на нагрів використовують розділові блоки BS (однопортові і багатопортові) [2]. Найбільш ефективні трьохтрубні системи, коли є окрема газова труба з високою температурою холодоагенту, використовуваного для нагріву повітря. Система з ре- куперацією має високій ESEER = 8. Такі системи дозволяють створити ідеальні умови для роботи (наприклад в офісах) на південній і північній фасадних сторонах, коли в північних приміщеннях повітря треба нагрівати, а в південних охолоджувати. Частина тепла при цьому буде "безкоштовною", тобто тепло, відібране в південних приміщеннях, буде передаватися повітрю в північних.

Трьохтрубна технологія Daikin витрачає менше енергії для рекуперації тепла, що істотно підвищує ефективність цього процесу. Вторинна переробка тепла за рахунок рекуперації може забезпечити $\mathrm{SCOP}=10$.

Рекуперація тепла в громадських об'єктах, наприклад в готельних комплексах, де в залежності від орієнтації вікон в номерах, інших локальних джерел теплоприпливів і тепловтрат можуть бути реалізовані режими охолодження і нагрівання в різних номерах.

Синергетичний ефект від цих підходів дозволяє отримати максимальну ефективність.

\section{2 Удосконалення основних апаратів i агрега- тів в сучасних багатозональних системах кон- диціювання повітря}

\section{Компресори}

Інверторне керування і система датчиків забезпечують змінну температуру холодоагенту, малі значення пускового струму і безступінчасте регулювання продуктивності.

Амплітудно-імпульсна модуляція дозволяє наблизити струм ланцюга харчування інверторної схеми до синусоїдальної формі, що забезпечує плавність обертання і підвищення ККД. Привід від синхронного електродвигуна постійного струму забезпечує підвищену енергоефективність за рахунок підсумовування основного та реактивного крутного моменту і застосування неодимових магнітів, що забезпечують коерцетивну силу в кілька разів більшу, ніж феритові магніти.

Механізм 3 платформою, що підлаштовується (Frame Compliance Mechanism-FCM), підтискає рухливу спіраль до нерухомої, що зменшує втрати, пов'язані з перетіканням газу. Заповнення порожнин рідким мастилом високого тиску знижує тертя, втрати, пов'язані з осьовими навантаженнями, підвищує енергоефективність компресорів.

Технологія двофазного уприскування холодоагенту [2] забезпечує стабілізацію теплопродуктивності при зниженні зовнішньої температури.

У серії KXZ встановлено вдосконалені спіральні компресори, які мають по 2 додаткових випускних клапана, що дозволяє більш оптимально управляти тиском в компресорі, особливо на низькій частоті, знижуючи скачки в процесі стиснення холодоагенту і енергоспоживання.

\section{Вентилятори}

Двигун постійного струму 3 зовнішнім ротором більшого діаметру дозволяє отримати велику діючу силу при тому ж магнітному полі.

Оптимізація синусоїдального інвертора забезпечує більш плавне обертання і підвищення ККД електродви- 
гуна, яке найбільш істотно при низьких швидкостях, тобто в міжсезоння.

Досконалий направляючий апарат осьового вентилятора зовнішнього блоку CITY MULTI дозволяє отримати підвищений статичний напір при меншій частоті обертання і меншому енергоспоживанні.

\section{Теплообмінник}

Більш ефективне використання теплообмінника зменшує теплообмін між перегрітим газом і недогрітою рідиною.

У новій серії KXZ була істотно поліпшена конструкція теплообмінника. Збільшена теплопередавальна поверхня і система розподілення холодоагенту з використанням схеми "павук" з мікроканалами, яка дозволила зменшити кількість холодних точок і відповідно підвищити надійність роботи при низьких температуpax.

Нами розглянуті лише деякі технології і елементи, вдосконалення яких безпосередньо підвищує енергоефективність і знижує споживання електроенергії в річному циклі використання багатозональних системах кондиціювання повітря (БСКП) .

Згадані в цьому розділі фірми і багато інших виробників БСКП в каталогах і проспектах представляють десятки переваг і зручностей, що доступні при використанні.

Необхідно також відзначити постійну роботу провідних світових фірм, які виробляють БСКП, над системами їх управління та програмним забезпеченням, над полегшенням їх експлуатації та використання таймерів, що настроюються на тривалий термін, по запрограмованій автоматичній підтримці і зміні параметрів мікроклімату в процесі добового, тижневого, а іноді і більш тривалого періоду.

Великих успіхів досягла індустрія забезпечення мікроклімату в технологіях фільтрації, бактерицидної обробки і корисної іонізації повітря в БСКП.

Сполучення зовнішніх ланцюгів при конфігуруванні модулів МЗС дозволяє отримати системи холодо- та теплопродуктивності від 10 до 180 кВт в одному модулі. Фірми пропонують варіанти найбільш компактних і найбільш енергоефективних модулів. Модульний принцип залишає можливість творчої оптимізації БСКП, починаючи з етапу проектування, з урахуванням всіх особливостей конкретного об'єкта. Для цього використовуються програми-конфігуратори, які безперервно вдосконалюються.

Для більш зрозумілого і об'єктивного порівняння БСКП ми розглядали показники 4-х японських фірм світових лідерів в секторі виробництва кліматичного обладнання: Daikin, Mitsubishi Electric, Fujitsu, Mitsubishi Heavy.

Необхідно відзначити, що енергозбереження найбільш ефективно, якщо воно проводиться на всіх стадіях життєвого циклу об'єкта. від вибору на етапі проектування кліматичного обладнання та величини теплового опору огороджень, опрацювання доцільності використання поновлюваних джерел енергії (ВДЕ), об'єктивного і висококваліфікованого енергоаудиту за результатами першого року експлуатації і енергоменеджменту до моменту капітальної модернізації об'єкта або його повної зупинки перед утилізацією обладнання.

\section{3. Приклад підбору енергоефективного облад- нання багатозональних систем кондицію- вання}

Вибір номіналу зовнішнього блоку і режиму його завантаження 3 метою отримання найбільшої енергоефективності та енергозбереження в річному циклі розглянуто на прикладі FUJITSU. Підбір обладнання зроблений за програмою розрахунку $[3,4,5]$ з урахуванням функції

Розглянемо режим кондиціювання на прикладі двох зовнішніх блоків: AJY072LALBH і AJY090LALBH.

На рисунку 1 наведена залежність фактичної холодопродуктивності $q_{\mathrm{x}}\left(t_{\mathrm{n}}\right)$, фактичної споживаної потужності $p_{\mathrm{f}}\left(t_{\mathrm{n}}\right)$ і їх відносини $\operatorname{EER}\left(t_{\mathrm{n}}\right)$, що визначає ефективність роботи МЗС AJY072LALBH на охолодження, від зовнішньої температури $t_{\mathrm{n}}$.

На рисунках 2 та 3 наведені залежності енергетичної ефективності роботи БСКП від сумарного індексу підключених внутрішніх блоків.

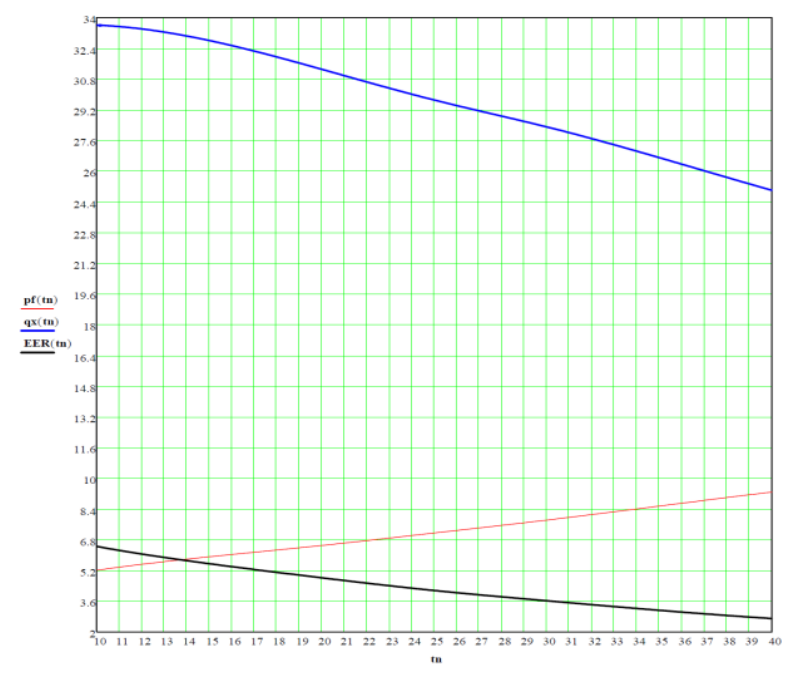

Рисунок 1 - Залежність фактичної холодопродуктивності $q_{\mathrm{x}}\left(t_{\mathrm{n}}\right)$, фактичної споживаної потужності $p_{\mathrm{f}}\left(t_{\mathrm{n}}\right)$ та їх відносини EER $\left(t_{\mathrm{n}}\right)$ від зовнішньої температури $t_{\mathrm{n}}$

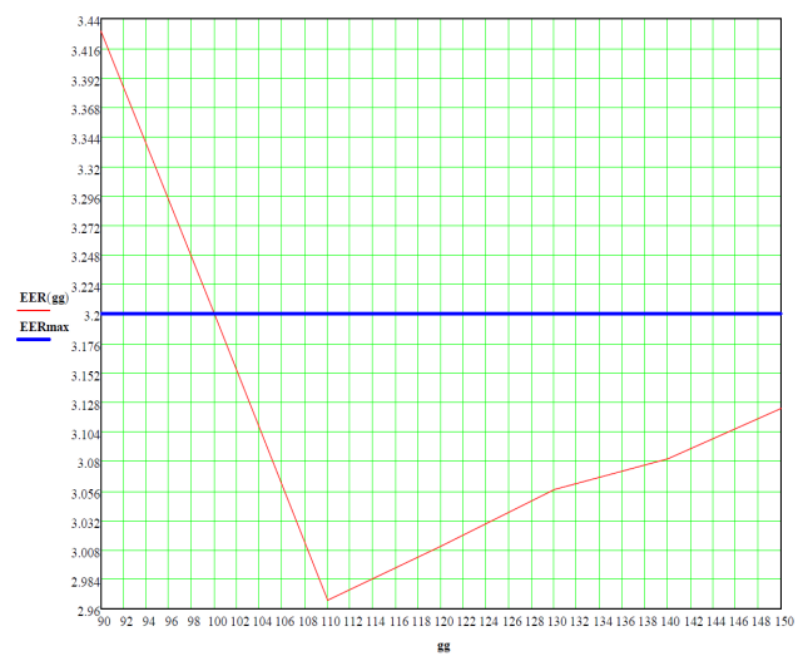

Рисунок 2 - Залежність енергетичної ефективності роботи БСКП від сумарного індексу (сумарної номінальної холодопродуктивності у відсотках) підключених внутрішніх блоків. 


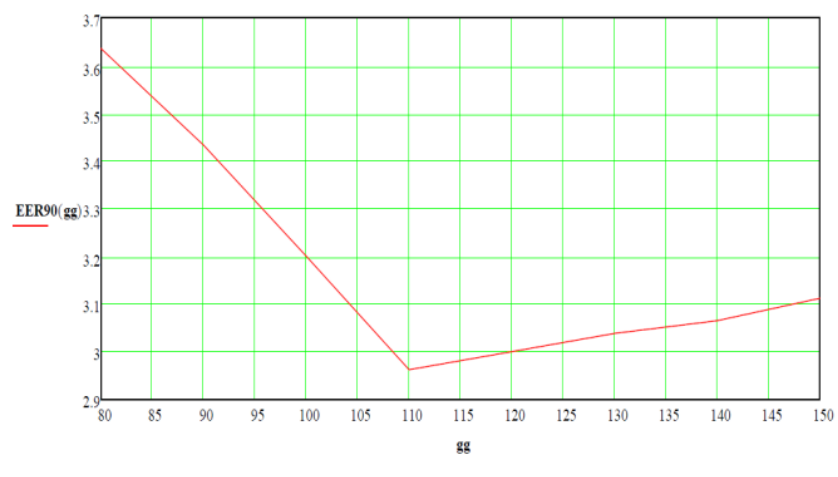

gg, \%

Рисунок 3 - Залежність енергетичної ефективност роботи БСКП від сумарного індексу (сумарної номінальної холодопродуктивності) підключених внутрішніх блоків.

Ця оціночна методика може бути використана для спільного вибору агрегату припливно-витяжної вентиляції 3 рекуперацією, інверторного кондиціонера i конструкції відповідних зовнішніх огороджень на ранній стадії проектування. При необхідності на стадії робочого проекту може бути виконаний перевірочний уточнений розрахунок, а за підсумками першого року експлуатації звірка уточненого розрахунку з витратою електроенергії за лічильником. В даному прикладі визначений термін окупності агрегатів з рекуперацією, обраний рекуператор, проведена спільна оптимізація капітальних і експлуатаційних витрат на розглянуті варіанти комплектів теплозахисту і енергозберігаючого обладнання за величиною цільової функції (1).

Графічне зображення залежностей фактичної потужності і холодопродуктивності від зовнішньої температури відповідає таблицями фірмових даних. Також видно, що при збільшенні температури коефіцієнт енергетичної ефективності БСКП зменшується. Однак в сучасних програмах управління числами оборотів компресора і температурою холодоагенту сезонне і річне споживання електроенергії буде значно нижче, ніж в системах без такого регулювання, тому сезонний коефіцієнт теплоефективності таких БСКП набагато вище.

При використанні меншого типономінала зовнішнього блок AJY072LALBH необхідно витрачати більшу потужність - 7 кВт замість 6,16 кВт при використанні зовнішнього блоку AJY090LALBH. Тобто цей зовнішній блок більшого типономінала при такій температурі буде працювати 3 великим $\mathrm{EER}=3,636$, ніж AJY072LALBH, який в цих же умовах буде відповідати $\mathrm{EER}=3,2$.

Зі сказаного ясно, що максимальна теплова потужність / холодопродуктивність БСКП повинна відповідати максимально теплоприпливам (тепловтратам) кондиціонера об'єкта, а річна витрата електроенергії буде залежати від досконалості обладнання, що автоматично підтримує з необхідною точністю задані сезонні температури повітря в об'єкті, в залежності від зміни зовнішніх умов нестаціонарного режиму тепловиділень і вологовиділення всередині об'єкта. Таке вдосконалення функціональних параметрів БСКП спільно з їх постійним вдосконаленням в частині надання більш повного комфорту користувачам, враховуючи шум і відносну вологість, та вдосконалення екологічної безпеки їх роботи, є сучасним трендом розвитку кліматичної техніки. Конкретний термін окупності БСКП із зовнішнім блоком (модулем) більшого типономінала в порівнянні з блоком (модулем) меншого типономіналу за рахунок економіі електроенергії можливо визначити за апробованою методикою розрахунку теплоприпливів з врахуванням нестаціонарності $[5,6]$ і тепловтрат об'єкта протягом річного циклу для середньомісячних зовнішніх температур [4,5]. У зазначеному джерелі наведені діаграми для мінімальних, середніх і максимальних середньомісячних температур в Одесі, виконані за даними Метеопост-Климат Одеса. 3 огляду на тенденцію збільшення середньорічних температур в зв'язку зі зміною клімату землі мабуть можна використовувати для зазначеної мети діаграму максимальних середньомісячних температур .

Оскільки на вибір типономіналу багатозональних систем кондиціювання повітря крім розглянутих енергетичних параметрів впливають багато інших факторів, в тому числі і суб'єктивні побажання замовника, раціонально на стадії проектування виконати помісячний розрахунок споживання електроенергї̈ та її вартість для актуальних тарифів.

\section{4. Висновок}

У даній роботі визначені шляхи підвищення ефективності багатозональних систем кондиціювання повітря та за розробленою програмою підібране кліматичне обладнання 3 урахуванням цільової функції спільної оптимізації сумарної величини капітальних і експлуатаційних витрат на тепловий захист приміщень і кліматичне енергозберігаюче обладнання протягом терміну їх експлуатації.

При підборі обладнання враховується вплив чинників (мінлива температура холодоагенту, інверторний привід, рекуперація) та параметрів обладнання (компресор, вентилятор, теплообмінники, фільтри.)

Враховуючи ці фактори проведений експрес-аналіз для вибору моделі зовнішнього блока VRF на підставі таблиць фірм-представників та проведені розрахунки.

Розроблена оціночна методика може бути використана для спільного вибору агрегату припливновитяжної системи кондиціювання повітря з рекупераці$€ ю$, інверторного кондиціонера і конструкції відповідних зовнішніх огороджень на ранній стадії проектування.

Результати математичного моделювання дозволяють визначити енергоефективне обладнання багатозональних систем кондиціюванням повітря при врахуванні чинників та параметрів оптимізації.

\section{Литература}

1. Табунщиков Ю. А. Математическое моделирование и оптимизация тепловой эффективности зданий [Текст] / Ю.А.Табунщиков, М.М. Бродач. - М.: АВОКПРЕСС. - 2002. - 194 с.

2. Перепека В. И. Расчеты систем кондиционирования и вентиляции [Текст] / В.И., Перепека, Н.В. Жихарева Одесса: «ТЭС», 2014. - 240 с. 
3. Брух В.В. Парадоксы традиционной методики расчета VRF систем кондиционирования воздуха [Текст]// Брух В.В. / СОК. 2005. - №5. - С. 62-64.

4. Zhikhareva N. Modeling of energy effivient air condition // N.V Zhikhareva. / The scientific method. Poland - 2017. - No. 3. - P. 3-6.

5. Zhikhareva N. Optimization of conditionsng system for fremises with non stasionari heat exchanger // $\mathrm{N}$.
Zhikhareva. / Norwegian Journal of development of the International Science 2017. Vol. 2. No 5. P. 94-99.

6. Жихарєва Н. В. Математичне моделювання нестаціонарного теплообміну приміщень [Текст]// Н. В. Жихарєва, М. Г. Хмельнюк / Холодильна техніка та технологія. 2016. - Том 52, випуск 6. - С. 75-79.

Отримана в редакції 03.03.2017, прийнята до друку 06.06.2017

\title{
Ways to Increase the Energy Efficiency of Multi-Zone VRF Air Conditioning Systems
}

\section{N. V. Zhikhareva}

Odessa National Academy of Food Technologies, 112 Kanatnaia str., Odessa, 65039, Ukraine

\begin{abstract}
Ways to increase the energy efficiency of multi-zone air conditioning systems, some technologies and elements, the improvement of which directly increases energy efficiency and reduces electricity consumption in the annual cycle of using air conditioning systems based on the energy balances of thermal processes in VRF are considered. With the help of mathematical simulation methods of circuit-technical solutions and equipment operating modes of microclimate maintenance systems in public facilities using modern multi-zoned air conditioning systems the model for the selection of a multi-zone air conditioning system has been developed that takes into consideration the following factors: variable refrigerant temperature, inverter drive, recovery) and equipment (compressor, fan, heat exchangers, filters. The results of calculations based on the developed express methodology that takes into account non-stationary heat and moisture external and internal loads and the influence of factors with the selection of modern equipment are shown. The energy saving capabilities were carried out when calculating the universal objective function and mathematical modeling software by determining the payback period and the objective function values for the compared options. The comparative analysis is carried out based on the developed mathematical model of Daikin, Mitsubishi Electric, Fujitsu, Mitsubishi Heavy for objects operating during the daily cycle in extreme non-stationary mode.
\end{abstract}

Key words: Optimization; Energy Saving; Air Conditioning; Simulation; Non-Stationary Load; Inverter; Compressor; Fan; Heat Exchanger.

\section{References}

1. Tabunshchykov, Y. A., Brodach, M. N. (2002) Matematycheskoe modelrovanye and thermal optimization of the effectiveness buildings. M. Avok-PRESS, $194 \mathrm{p}$.

2. Perepeka, V. I., Zhikhareva, N. V. (2014) The calculations of air conditioning and ventilation. Odessa «TEC», $240 \mathrm{p}$.

3. Brukh, V.V. (2005) Paradoxes of the traditional method of calculating VRF air conditioning systems. SOK, No. 5, 62-64.
4. Zhikhareva, N. (2017) Modeling of energy effivient air condition. The Scientific Method. Poland, No.3, 3-6.

5. Zhikhareva, N. (2017) Optimization of conditionsng system for fremises with non stasionari heat exchanger. Norwegian Journal of Development of the International Science, 2 (5), 94-99.

6. Zhikhareva, N. V., Khmelniuk, M. G. (2016) Mathematical modeling of bulding unsteady heat transfer. Refrigeration Engineering and Technology, 52 (6), 75-79. DOI: http://dx.doi.org/10.15673/ret.v52i6.479 